\title{
A Model to Detect Autochthonous Group 1 and 2 Brazilian Vaccinia virus Coinfections: Development of a qPCR Tool for Diagnosis and Pathogenesis Studies
}

\author{
Rafael Calixto ${ }^{1}$, Graziele Oliveira ${ }^{1}$, Maurício Lima ${ }^{1}$, Ana Cláudia Andrade ${ }^{1}$, \\ Giliane de Souza Trindade ${ }^{1}$, Danilo Bretas de Oliveira ${ }^{1,2}$ and Erna Geessien Kroon ${ }^{1, *}$ \\ 1 Laboratório de Vírus, Departamento de Microbiologia, Universidade Federal de Minas Gerais, \\ Belo Horizonte 31270-901, Minas Gerais, Brazil; calixtomicro@yahoo.com.br (R.C.); \\ graziufmg@yahoo.com.br (G.O.); maurili15@hotmail.com (M.L.); ana.andrade2008@hotmail.com (A.C.A.); \\ gitrindade@yahoo.com.br (G.d.S.T.); danilobretas@yahoo.com.br (D.B.d.O.) \\ 2 Faculdade de Medicina de Diamantina, Universidade Federal dos Vales do Jequitinhonha e Mucuri, \\ Dimantina 39100-000, Minas Gerais, Brazil \\ * Correspondence: kroone@icb.ufmg.br or ernagkroon@gmail.com; Tel.: +55-031-99949-1240
}

Received: 1 December 2017; Accepted: 29 December 2017; Published: 30 December 2017

\begin{abstract}
Vaccinia virus (VACV) is the etiological agent of bovine vaccinia (BV), an emerging zoonosis that has been associated with economic losses and social effects. Despite increasing reports of BV outbreaks in Brazil, little is known about the biological interactions of Brazilian VACV (VACV-BR) isolates during coinfections; furthermore, there are no tools for the diagnosis of these coinfections. In this study, a tool to co-detect two variants of $V A C V$ was developed to provide new information regarding the pathogenesis, virulence profile, and viral spread during coinfection with $V A C V$-BR isolates. To test the quantitative polymerase chain reactions (qPCR) tool, groups of BALB/c mice were intranasally monoinfected with Pelotas virus 1-Group II (PV1-GII) and Pelotas virus 2-Group I (PV2-GI), or were coinfected with PV1-GII and PV2-GI. Clinical signs of the mice were evaluated and the viral load in lung and spleen were detected using simultaneous polymerase chain reactions (PCR) targeting the $A 56 R$ (hemagglutinin) gene of $V A C V$. The results showed that qPCR for the quantification of viral load in coinfection was efficient and highly sensitive. Coinfected mice presented more severe disease and a higher frequency of $V A C V$ detection in lung and spleen, when compared to monoinfected groups. This study is the first description of PV1 and PV2 pathogenicity during coinfection in mice, and provides a new method to detect $V A C V$-BR coinfections.
\end{abstract}

Keywords: Vaccinia virus; qPCR; coinfection; mice model

\section{Introduction}

Vaccinia virus (VACV) is a member of the family Poxviridae, genus Orthopoxvirus, which includes other members, such as Variola virus, Cowpox virus and Monkeypox virus [1,2]. Variola virus was one of the most terrible pathogens in human history, but it was declared eradicated in 1980 after an intensive vaccination campaign promoted by the World Health Organization (WHO) [3]. VACV can induce serological cross-reactivity against other orthopoxvirus (OPV) members and was used in the WHO campaign $[1,3]$.

$V A C V$ is the etiological agent of bovine vaccinia (BV), an exanthematous disease that causes ulcerative lesions in cattle and humans, economic losses, and social effects in South America and Asia, especially in Brazil [4-8]. The clinical signs of BV range from papules and vesicles to scabs, mainly on the udder and teats of bovines. In humans, lesions occur primarily on the hands and arms, and other 
symptoms, such as fever, myalgia, headache, arthralgia, and lymphadenopathy, have been described and there is a significant economic impact on rural workers [1,6].

The natural circulation of $V A C V$ in Brazil has been often reported since 1999, and is associated with exanthematous outbreaks [6,7,9-12]. Many studies have shown biological and genetic variations among Brazilian VACV (VACV-BR) isolates. This variability allowed $V A C V$-BR clustering into two distinct groups: Group 1 (GI) and group 2 (GII). These two groups are supported by biological features, such as virulence in a BALB/c mouse model and plaque phenotype in BSC-40 cells. GII isolates display larger plaque sizes and are virulent to mice, unlike GI [4,12-16]. Furthermore, molecular diversity is observed in specific VACV genes, such as the hemagglutinin gene (A56R), A-type inclusion body gene $(A 26 L)$, and chemokine-binding protein gene (C23L), and these genes have been used in phylogenetic studies and further confirmed the dichotomy between GI and GII VACV-BR. The A56R sequence contains a signature deletion of $18 \mathrm{nt}$, present in the sequences of GI isolates and absent of GII isolates, which is used as a "molecular marker" for VACV-BR group identification $[9,13,16-18]$. The circulation of the two VACV-BR groups was demonstrated in the same outbreak in 2006 [4] and in the same host as a coinfection was only identified later $[15,16]$. In 2008, a VACV outbreak, caused by viruses of the two VACV-BR groups, was described in horses from Pelotas City, Brazil. This coinfection presented hemorrhagic lesion and scabs in the muzzles and nostrils of animals $[15,19]$. The VACV isolates were named Pelotas virus 1-Group II (PV1-GII) and Pelotas virus 2-Group I (PV2-GI) and were used in this study [15]. Despite increasing reports of outbreaks related to $V A C V$-BR, little is known about its biological relevance, virulence profile and viral spread during coinfections with $V A C V$-BR of GI and GII. Moreover, until now, there have been no established tools for the diagnosis or pathogenesis studies of coinfections with $V A C V$-BR of GI and GII. As the best well-characterized molecular difference of the two groups is the $A 56 R$ sequence which contains a signature deletion of $18 \mathrm{nt}$ for GI, it results in the difficulty of developing a test for direct quantification of this group.

In this study, a new tool for the detection and quantification of $V A C V$ isolates in coinfections was developed and could be used as a tool to provided new information regarding the diagnosis, pathogenicity, virulence profile, and viral spread during a coinfection with $V A C V$-BR isolates. Our method aims to improve screening in outbreaks and consequently the study of $V A C V$-BR GI/GII coinfections pathogenesis.

\section{Materials and Methods}

\subsection{Ethical Statement}

This study was approved by the Committee of Ethics in Animal Use from the Universidade Federal de Minas Gerais (CEUA/UFMG, Belo Horizonte, Brazil), protocol number 207/2010.

\subsection{Cells and Viruses}

African green monkey kidney BSC-40 (ATCC-CRL-2761) and VERO (ATCC-CCL-81) cells were maintained in a $5 \% \mathrm{CO}_{2}$ atmosphere at $37{ }^{\circ} \mathrm{C}$, in Eagle's Minimum Essential Medium (MEM) (Gibco BRL, Invitrogen, Carlsbad, CA, USA), supplemented with $5 \%$ fetal bovine serum (FBS) (Cultilab, Brazil), $25 \mu \mathrm{g} / \mathrm{mL}$ fungizone (Amphotericin B) (Cristália, São Paulo, Brazil), $500 \mathrm{U} / \mathrm{mL}$ penicillin and $50 \mu \mathrm{g} / \mathrm{mL}$ gentamicin (Schering-Plough, São Paulo, Brazil). VERO cells were used for viral replication and the BSC-40 cells were used for viral plaque phenotypes and titration. The VACV used in the study, PV1 and PV2, were isolated from clinical specimens of horses during an equine vaccinia outbreak $[15,19]$.

\subsection{Animal Experiments}

For all animal experiments, five-week-old male Balb/c mice were used, and were maintained in micro-isolators located in a ventilated animal caging system (Alesco Ltd., Campinas, SP, Brazil), and were provided with commercial mouse food and water, ad libitum, in controlled lighting (12 h 
light-12 h dark), humidity $(60-80 \%)$ and temperature $\left(22 \pm 1{ }^{\circ} \mathrm{C}\right)$. The mice of all groups were anesthetized via intraperitoneal injection of $0.1 \mathrm{mg}$ of ketamine and $0.01 \mathrm{mg}$ of xylazine in $0.9 \%$ PBS, per gram of animal weight. The four groups of five mice were inoculated intranasally with $10 \mu \mathrm{L}$ of viral suspension: PV1-GII $1 \times 10^{6}$ p.f.u.; PV2-GI $1 \times 10^{6}$ p.f.u.; PV1-GII+ PV2-GI $5 \times 10^{5}$ p.f.u. of each sample; a negative control group was inoculated with $10 \mu \mathrm{L}$ of PBS, as previously described [14]. Mice were weighed daily, and other clinical signs were recorded for 30 days post infection (d.p.i.). To study viral tropism, the mice were euthanized with an overdose of anesthetics (three times the anesthetic solution) and were perfused with PBS-EDTA intracardiac and those animals had their spleens and lungs collected on 5 d.p.i. [14]. The collected organs were weighed and macerated with the Beadbeater 16 homogenizer in $500 \mu \mathrm{L}$ of PBS, with glass beads in the microtubes thread. Three cycles of freezing and thawing were performed in order to release the viral particles from the cells. The cells were then centrifuged at $425 \times \mathrm{g}$ for $10 \mathrm{~min}$ at $4{ }^{\circ} \mathrm{C}$ and the supernatants were used for DNA extraction and plaque phenotype assays. For DNA extraction, the High Pure Viral Nucleic Acid Kit (Roche Diagnostics GmbH, Branchburg, NJ, USA) was used.

\subsection{Plaque Phenotype}

For plaque phenotype assays, BSC40 cells seeded in 6-well plates at $90-95 \%$ confluence were inoculated with the macerated tissues. After $1 \mathrm{~h}$ of adsorption $\left(37^{\circ} \mathrm{C}, 5 \% \mathrm{CO}_{2}\right)$, monolayers were washed twice with PBS and overlaid with solid medium, prepared by mixing equal parts (1:2) of $1 \%$ agarose and twice the standard concentration Eagle's minimum essential medium (MEM) supplemented with $2 \%$ FBS. After $48 \mathrm{~h}$ of incubation $\left(37{ }^{\circ} \mathrm{C}, 5 \% \mathrm{CO}_{2}\right)$, cells were fixed with formaldehyde and stained with crystal violet for plaque size analysis.

\section{5. $q P C R$}

The qPCR consisted of two simultaneous reactions, A and B, targeting the hemagglutinin gene [20]. DNA amplifications were carried out in duplicate in a StepOne ${ }^{\mathrm{TM}}$ thermocycler (Applied Biosystems, Foster City, CA, USA). qPCR took place in a total volume of $10 \mu \mathrm{L}$, containing $5 \mu \mathrm{L}$ of Master Mix SYBR Green (Applied Biosystems, manufactured by Roche, Branchburg, NJ, USA), $200 \mathrm{nM}$ of each of the forward and reverse primers (Table 1 ) and 10-50 ng of each DNA sample.

Table 1. Real-time PCR primers.

\begin{tabular}{cccc}
\hline Reaction & Primers & Sequence (5'-3') & Specificity \\
\hline \multirow{2}{*}{ A } & A56R-gen F & AACCACCGATGATGCGGAT & \multirow{2}{*}{ Amplify all VACV Group I and II. } \\
& A56R-gen R & TGCCACGGCCGACAATATAA & Amplify all VACV that do not present \\
& A56R-BVV-nDEL F & GCGGATCTTTATGATACGTACAATG & the 18nt deletion Group II [20]. \\
\hline
\end{tabular}

Figure 1 shows the target DNA regions for the primers used in this study. Thermal cycling conditions were as follows: one cycle at $95{ }^{\circ} \mathrm{C}$ for $10 \mathrm{~min}$, followed by 40 cycles at $95{ }^{\circ} \mathrm{C}$ for $10 \mathrm{~s}$, and $58{ }^{\circ} \mathrm{C}$ for $40 \mathrm{~s}$; and a melting curve analysis, consisting of $95^{\circ} \mathrm{C}$ for $15 \mathrm{~s}, 58^{\circ} \mathrm{C}$ for $15 \mathrm{~s}$, followed by increasing the temperature by $1{ }^{\circ} \mathrm{C}$ every $2 \mathrm{~s}$ until $95^{\circ} \mathrm{C}$ was reached, and then $95^{\circ} \mathrm{C}$ for $15 \mathrm{~s}$. Standard curves were constructed by plotting four dilutions of each prototype DNA against the corresponding cycle threshold value $(\mathrm{Ct})$; melting curves were used to ensure there were no non-specific amplifications. 

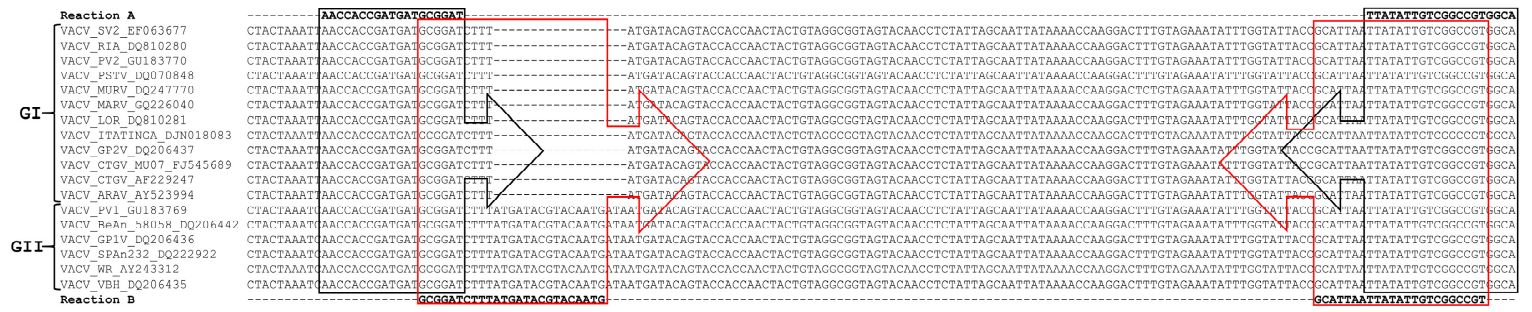

Figure 1. Alignment of the target DNA region within the A56R gene of the Vaccinia virus used for primer sequence design. The virus sequences were obtained from GenBank and the accession numbers are shown in the figure. The alignment was performed using the standard parameters of CLUSTAL W. The primers used in Reaction A (A56R-gen F and A56R-gen R) are outlined in black and, for Reaction B (A56R-BVV-nDEL F and A56R-generic R), are in red.

For standardization, a curve was made using lungs from uninfected Balb/c mice, spiked with $10^{6}, 10^{5}, 10^{4}, 10^{3}, 10^{2}$ or $10^{1}$ p.f.u. of PV1-GII and PV2-GI. For validation lungs from uninfected Balb/c mice were spiked with $10^{5}$ p.f.u. of each sample (PV1-GII and PV2-GI). DNA was extracted and qPCR reactions $A$ and $B$ were performed. An equation for the differential viral load calculation was proposed:

$$
\begin{aligned}
& \text { [ ] } V A C V \mathrm{GI}=[\text { ] } V A C V \text { total }(\mathrm{GI}+\mathrm{GII})-[\text { [ } V A C V \mathrm{GII} \\
& \text { [ ] VACV GI }=3.38 \times 10^{6}-1.68 \times 10^{6} \\
& \text { [ ] VACV GI }=1.70 \times 10^{6} \\
& \mathrm{GI}=1.70 \times 10^{6} \text { and GII }=1.68 \times 10^{6}
\end{aligned}
$$

\subsection{Statistical Analyses}

All results were plotted using GraphPad Prism (GraphPad Software, version 6.01, La Jolla, CA, USA) and compared using one-way ANOVA and Tukey's multiple comparisons test, and two-way ANOVA using the Bonferroni method. In all tests, $p$-values $<0.05$ were considered statistically significant.

\section{Results}

\subsection{Development of qPCR Tool}

The efficiency of primers developed for the $A 56 R$ gene in $V A C V$ coinfection, for Reaction A, showed an efficiency of $96.6 \%$ and an $\mathrm{R}^{2}$ value of 0.971 ; for Reaction $\mathrm{B}$, an efficiency of $94.0 \%$ and a value of $R^{2}$ of 0.983 (Figure 2) were found. The detection limit of the assay was 2 p.f.u./mg of tissue and the reaction was efficient in different matrices such as lung, gut, and spleen.

The analysis of only one quantitative PCR (qPCR) peak fluorescence reaction was not able to distinguish the VACV-BR groups and to identify the presence of the deletion of $18 \mathrm{nt}$ in A56R gene of GI viruses. In qPCR Reaction A, the fluorescence peaks were within $0.5^{\circ} \mathrm{C}$, making it difficult to rely on the melting (Tm) curve as a unique identifier for each PCR product (Tm GI: $75.8^{\circ} \mathrm{C}$ and Tm GII: $\left.76.3^{\circ} \mathrm{C}\right)$. In Reaction B, GI is not amplified. 

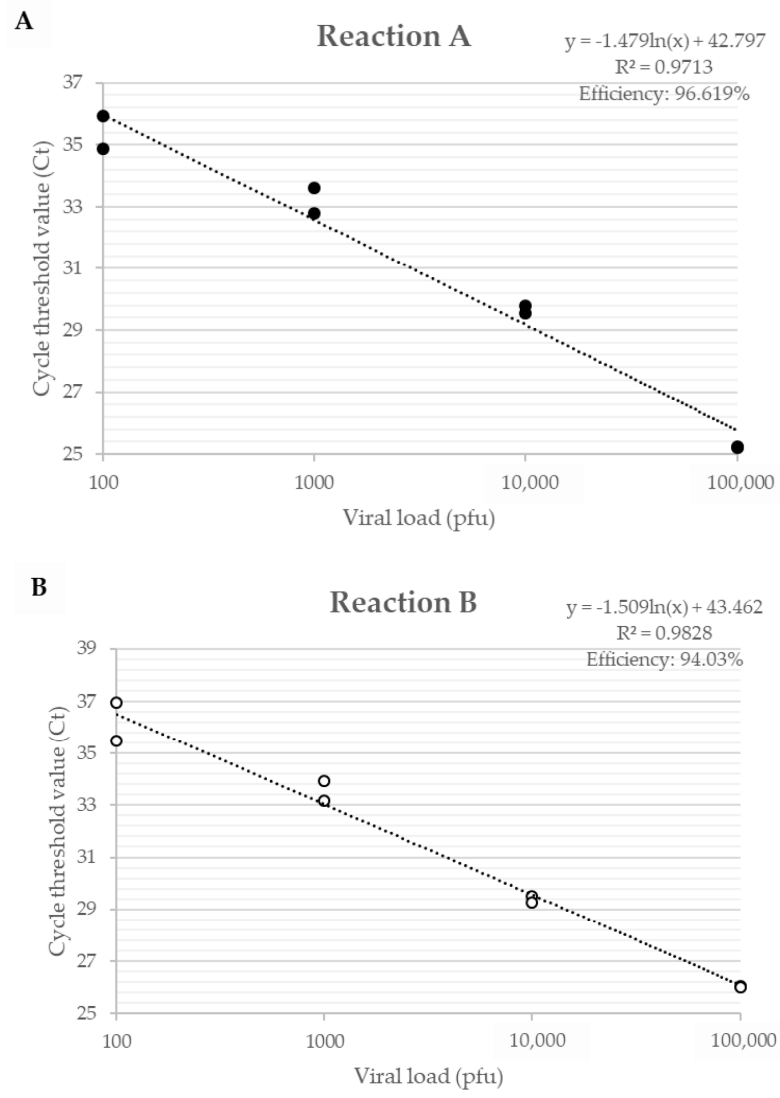

Figure 2. Efficiency curve of $A 56 R$ gene qPCR in coinfection of PV1-GII and PV2-GI. Uninfected Balb/c mice lungs were spiked with $10^{6}, 10^{5}, 10^{4}, 10^{3}, 10^{2}$ and $10^{1}$ p.f.u. of PV1-GII and PV2-GI. (A) in Reaction A shown in black circles, primers $A 56 R$-gen F and A56R-gen R were used; and (B) in Reaction B shown in white circles, primers $A 56 R$-BVV-nDEL F and $A 56 R$-generic $\mathrm{R}$ were used.

\subsection{A56R qPCR as a Tool to Study Pathogenesis and Viral Spread}

\subsubsection{Clinical Signs in Mice: Coinfected Versus Monoinfected}

Mice that were inoculated with PV1-GII $\left(1 \times 10^{6}\right)$ and coinfected (PV1-GII + PV2-GI with $5 \times 10^{5}$ of each) showed the first clinical signs, such as facial edema, fur ruffling, hunching of the back, dyspnea and severe weight loss from 4 to 15 d.p.i. The coinfected mice presented a slightly longer clinical manifestation compared to the PV1-GII group, which was not significant with respect to percent weight loss (PV1-GII vs. PV1-GII + PV2-GI). In the PBS and PV2-GI groups, no clinical signs or weight loss were observed. The only significant differences were the weight variation of PV1-GII and the co-infected group compared to the PBS group (Figure 3).

3.2.2. Coinfected Mice Present Higher Frequency of VACV Detection in Lungs and Spleens than Monoinfected Groups

Using Reaction A, which amplifies all $V A C V$, a positive qPCR was obtained in the lungs and spleen of $100 \%$ of the mice inoculated with PV1- GII and PV1-GII + PV2-GI and in $60 \%$ of the PV2-GI infected mice lungs and $80 \%$ of the spleens. Reaction B of qPCR, which amplifies only the GII A56R gene (inoculated with PV1), showed a high positivity (100\%) in lungs and only $60 \%$ of positivity in spleen (Figure 4A). This was confirmed by plaque phenotype assays (Figure 4B) of the lungs of four mice that were coinfected, which showed the presence of two viral populations (small plaques-PV2-GI and large plaques-PV1-GII). 


\subsubsection{Viral Load in Lung and Spleen}

The analysis of the viral loads in the lungs of mice in the monoinfected group (PV1) revealed an average viral load of almost two logs higher than monoinfected group (PV2-GI) (Figure 5A). A significant difference was observed when the viral loads of both monoinfected groups (PV1-GII and PV2-GI) were compared with each sample in coinfection (PV1-GII with PV1-GII + PV2-GI and PV2-GI with PV1-GII + PV2-GI) (Figure 5A). Differences about one log for PV1-GII groups and almost three logs between PV2-GI mice groups were observed (Figure 5A).

The differences between the monoinfected groups (PV1-GII or PV2-GI) in the spleens were irrelevant, demonstrating a higher concentration of viral DNA of GI in this tissue (Figure 5B). The viral load in spleens of PV2-GI monoinfected was very similar to that of PV2-GI from the coinfected group (PV1 + PV2) (Figure 5B). When the viral load of PV1-GII monoinfected with PV1-GI from the coinfected group (PV1-GII + PV2-GI) was compared, it showed a decrease of about one log with statistical significance (Figure $5 \mathrm{~B}$ ).

A

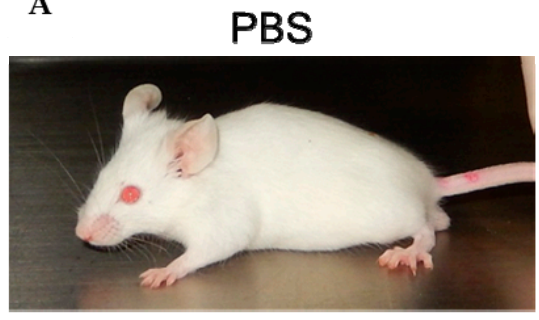

PV1

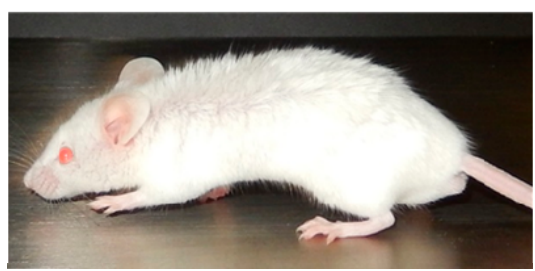

B

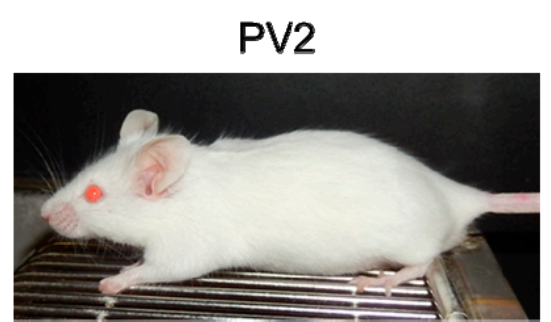

PV1+PV2

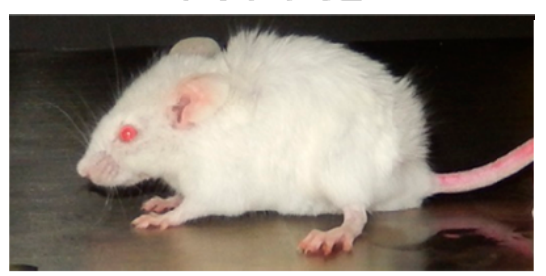

- PBS

- PV2

$\simeq$ PV1

- PV1+PV2

* $p<0,05$

$\because p<0,01$

$\Rightarrow p<0,001$

Figure 3. Clinical signs of Balb/c mice coinfected and monoinfected with PV1-GII and PV2-GI. Five-week-old male Balb/c mice were intranasally inoculated with $10 \mu \mathrm{L}$ of viral suspension: PV1-GII $1 \times 10^{6}$ p.f.u.; PV2-GI $1 \times 10^{6}$ p.f.u.; PV1-GII + PV2-GI $5 \times 10^{5}$ p.f.u. of each sample; and a negative control group was inoculated with $10 \mu \mathrm{L}$ of PBS. Clinical signs were observed on day 5 p.i and were recorded for 30 days post infection (d.p.i.). (A) In PBS and PV2-GI groups, no clinical signals were observed. Mice monoinfected with PV1-GII and coinfected (PV1-GII + PV2-GI) showed fur ruffling and hunching of the back. (B) The mice were daily weighed and relative mean weight was calculated. The error bars indicate standard deviations. PV1-GII: Pelotas virus 1 Group II; PV2-GI: Pelotas virus 2 Group I; PBS: phosphate-buffered saline. Asterisks indicate a statistically significant difference: ${ }^{*} p<0.05 ; * * 0.01 ; * * *<0.001$. 


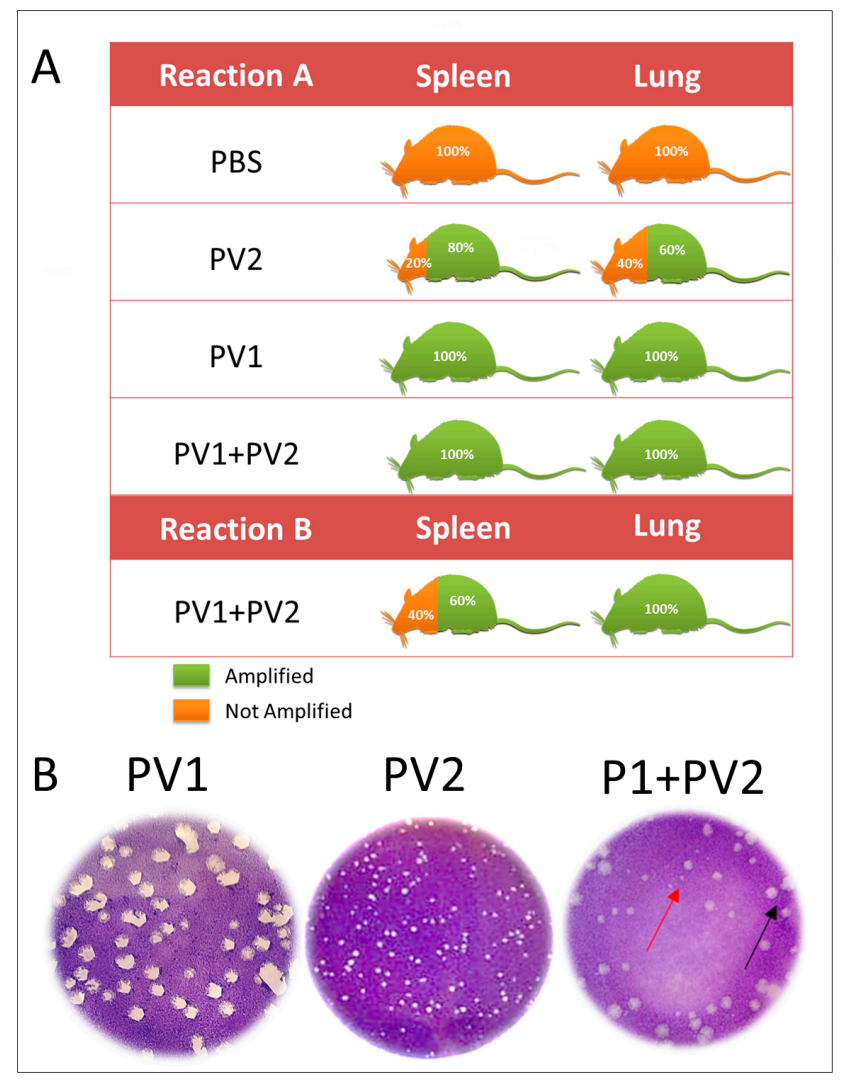

Figure 4. Detection of VAC-BR GI and GII in infected Balb/C mice: (A) qPCR detection of viral DNA from VACV A56R gene in mice spleen and lung samples. The results of Reaction A and Reaction $\mathrm{B}$ are represented. (B) Plaque phenotype assays of monoinfected (PV1-GII and PV2-GI) and coinfected mice showed two viral populations: small plaques-PV2 (red arrows) and large plaques-PV1 (black arrows). PV1-GII: Pelotas virus 1; PV2-GI: Pelotas virus 2; PBS: phosphate-buffered saline.

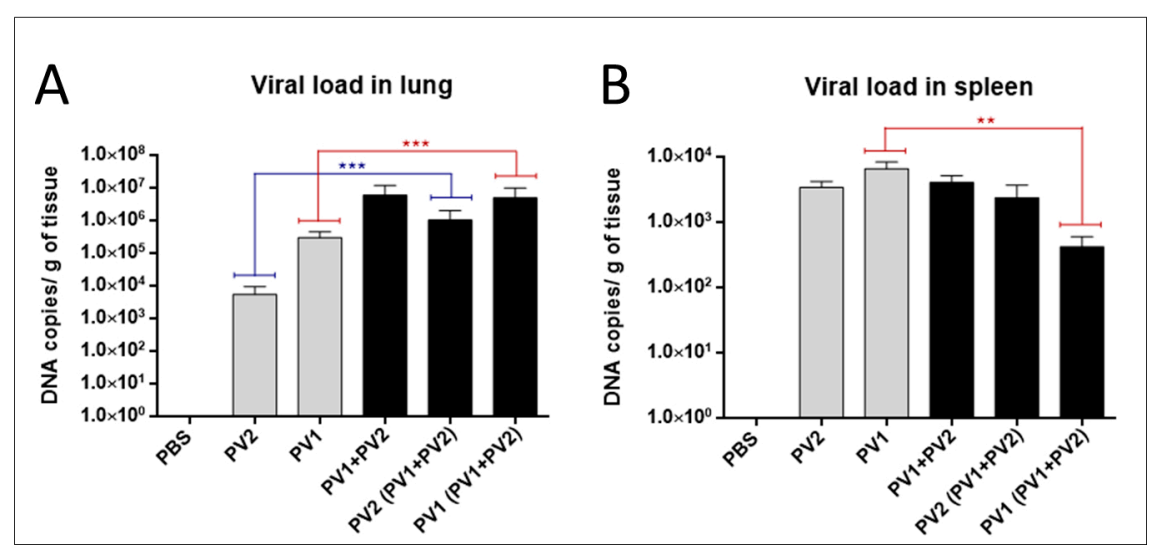

Figure 5. Viral load in mono or coinfected PV1-GII and PV2-GI mice. Viral loads in: lungs (A); and spleen (B) of Balb/c mice monoinfected (grey columns) and coinfected (black columns) with PV1-GII and PV2-GI were determined by qPCR. Comparisons between mono and coinfected groups are highlighted in red (PV1-GII groups) and blue (PV2-GI groups). The error bars indicate standard deviations. The statistical tests used were One-Way ANOVA and Tukey's multiple comparisons test Asterisks indicate a statistically significant difference: ${ }^{* *} p<0.01 ;{ }^{* *} p<0.001$. PV1: Pelotas virus 1; PV2: Pelotas virus 2; PBS: phosphate-buffered saline. 


\section{Discussion}

Notifications of natural cases of $V A C V$ infection have increased $[4,15,16]$, but this increase may be due to the development and improvement of study and detection techniques. qPCR is a rapid diagnostic tool, and is more sensitive than standard PCR; in addition, it allows acquiring molecular quantifications. Currently, multiplex real-time PCR has been described as a simple, reliable, and rapid method for the detection, identification and quantification of many kinds of viral coinfections [21-23]. In this way, qPCR assays have been used to detect and identify parapoxviruses and orthopoxviruses [24-27]. Here, we developed a new tool for the detection and quantification of VACV-BR isolates belonging to GI and GII during coinfections. This method was standardized under controlled conditions in animal model. Although the detection limit of 2 p.f.u./mg make its efficiency possible for many types of clinical samples more studies are needed to better clarify the total applications of method.

The qPCR assay to measure the viral load in coinfection was efficient and highly sensitive for different specimens (lung and spleen), showing a detection limit of 2 p.f.u./mg of tissue. The developed qPCR assay was useful as a detection system and in establishing the total viral load or relative viral load of VACV-GI and -GII in coinfections. The viral load could be measured because the efficiencies between two reactions are very close (96\% and $94 \%)$.

Previous studies have shown that isolates of $V A C V$-BR GII are virulent in murine model Balb/c, with weight loss and severe clinical signs, differently from GI, which is avirulent in this model [14]. Corroborating these data, the VACV isolates used in this work, in the monoinfected groups, PV1-GII and PV2-GI, followed the same pattern of virulence that has been previously described [15]. However, in this study, clinical signals in coinfected mice were evaluated and, unlike other studies conducted to date, this study evaluated animals until 30 d.p.i. when they had recovered from the infection [14-16]. Mice infected with the PV1-GII, a virulent representative of GII, and coinfected with PV2-GI, showed similar clinical signs, such as facial edema, fur ruffling, hunching of the back, dyspnea and severe weight loss. The weight variation data were significant at several points in the curve when we compared the control group to the groups infected with PV1-GII and co-infected (we use the two-way ANOVA test and Bonferroni method post-test).

The viral spread could be analyzed using this developed tool demonstrating a higher number of positive spleens samples $(80 \%)$, compared to lung samples $(60 \%)$ which is the primary site of inoculation in mice infected with PV2-GI. Furthermore, this analysis demonstrated the first description of spread of $V A C V$-BR samples of GI. Viral loads data and the spread of VACV-BR GI isolates have not yet been demonstrated in other studies, and these results demonstrate the tendency of a higher tropism for lungs of PV1-GII and PV2-GI in coinfections.

In primary infection site (lungs), the coinfections with both viruses have higher viral loads, contrasting with monoinfected groups. On the other hand, in spleen the viral load of the virulent group (PV1-GII) is low in case of coinfection compared with the group monoinfected by same virus. These results may suggest an intriguing interaction among host and viruses which could help to understand why these two $V A C V$ groups are found in coinfections on nature. It is too early to answer the many questions raised by these results and more studies are needed to generalize these characteristics for all VACV-BR GI and GII coinfections, or as exclusive of PV1-GII and PV2-GI isolates.

Studies have shown that plaque size phenotypes are one of the biological characteristics that make possible the differentiation of the two groups of $V A C V$-BR GI, with a small plaque phenotype, and GII with a large plaque phenotype $[10,15,16,28]$. Confirming biological characteristics of the plaque phenotype, the two viral populations (GI and GII) were detected in lungs of coinfected mice.

Using the developed tool of differential qPCR the first description of VACV-BR GI spread was possible. In previous studies, the GI virus could not be detected in mice lungs 5 d.p.i. [14]. Reports related to $V A C V$-BR groups coinfections increases as well as the difficulty to detect both groups at the same time by methods of viral isolation and DNA sequencing. The main focus of this study was to develop an efficient tool to facilitate screening during outbreaks and consequently the study of coinfection, and also clarify its possible medical and veterinary importance. 
Acknowledgments: We thank colleagues from Laboratório de Vírus (ICB-UFMG). This work was supported by research grants from Fundação de Amparo a Pesquisado Estado de Minas Gerais (FAPEMIG), Conselho Nacional de Desenvolvimento Científico e Tecnológico $(\mathrm{CNPq})$ and Coordenadoria de Aperfeiçoamento de Pessoal de Nível Superior (CAPES). EGK and GST are researchers from CNPq.

Author Contributions: Conceived and designed the experiments: Rafael Calixto, Graziele Oliveira, Giliane de Souza Trindade, Danilo Bretas de Oliveira, and Erna Geessien Kroon. Performed the experiments: Rafael Calixto, Graziele Oliveira, Maurício Lima, and Ana Cláudia Andrade. Analyzed the data: Rafael Calixto, Danilo Bretas de Oliveira, and Erna Geessien Kroon. Contributed reagents/materials/analysis tools: Giliane de Souza Trindade and Erna Geessien Kroon. Wrote the paper: Rafael Calixto, Graziele Oliveira, Danilo Bretas de Oliveira, and Erna Geessien Kroon. All authors read and approved final manuscript.

Conflicts of Interest: The authors declare no conflict of interest.

\section{References}

1. Damon, I.K. Poxviruses. In Fields Virology, 6th ed.; Knipe, D.M., Howley, P.M., Eds.; Lippincott, Williams and Wilkins: Philadelphia, PA, USA, 2014; Volume 2, pp. 2160-2184.

2. Moss, B. Poxviridae. In Fields Virology, 6th ed.; Knipe, D.M., Howley, P.M., Eds.; Lippincott, Williams and Wilkins: Philadelphia, PA, USA, 2014; Volume 2, pp. 2129-2159.

3. Fenner, F.; Henderson, D.A.; Arita, I.; Jezek, A.; Ladnyi, I.D. Smallpox and Its Eradication; World Health Organization Press: Geneva, Switzerland, 1988.

4. Trindade, G.S.; Lobato, Z.I.; Drumond, B.P.; Leite, J.A.; Trigueiro, R.C.; Guedes, M.I.; da Fonseca, F.G.; dos Santos, J.R.; Bonjardim, C.A.; Ferreira, P.C.; et al. Short report: Isolation of two vaccinia virus strains from a single bovine vaccinia outbreak in rural area from Brazil: Implications on the emergence of zoonotic orthopoxviruses. Am. J. Trop. Med. Hyg. 2006, 75, 486-490. [PubMed]

5. Singh, R.K.; Hosamani, M.; Balamurugan, V.; Bhanuprakash, V.; Rasool, T.J.; Yadav, M.P. Buffalopox: An emerging and re-emerging zoonosis. Anim. Health Res. Rev. 2007, 8, 105-114. [CrossRef] [PubMed]

6. Kroon, E.G.; Mota, B.E.; Abrahão, J.S.; da Fonseca, F.G.; de Souza Trindade, G. Zoonotic Brazilian Vaccinia virus: From field to therapy. Antivir. Res. 2011, 92, 150-163. [CrossRef] [PubMed]

7. Oliveira, D.B.; Assis, F.L.; Ferreira, P.C.; Bonjardim, C.A.; de Souza Trindade, G.; Kroon, E.G.; Abrahão, J.S. Group 1 Vaccinia virus zoonotic outbreak in Maranhao State, Brazil. Am. J. Trop. Med. Hyg. 2013, 89, 1142-1145. [CrossRef] [PubMed]

8. Franco-Luiz, A.P.; Fagundes-Pereira, A.; Costa, G.B.; Alves, P.A.; Oliveira, D.B.; Bonjardim, C.A.; Ferreira, P.C.; de Souza Trindade, G.; Panei, C.J.; Galosi, C.M.; et al. Spread of vaccinia virus to cattle herds, Argentina, 2011. Emerg. Infect. Dis. 2014, 20, 1576-1578. [CrossRef] [PubMed]

9. Damaso, C.R.; Esposito, J.J.; Condit, R.C.; Moussatché, N. An emergent poxvirus from humans and cattle in Rio de Janeiro State: Cantagalo virus may derive from Brazilian smallpox vaccine. Virology 2000, 277, 439-449. [CrossRef] [PubMed]

10. Trindade, G.S.; Emerson, G.L.; Carroll, D.S.; Kroon, E.G.; Damon, I.K. Brazilian vaccinia viruses and their origins. Emerg. Infect. Dis. 2007, 13, 965-972. [CrossRef] [PubMed]

11. Megid, J.; Appolinário, C.M.; Langoni, H.; Pituco, E.M.; Okuda, L.H. Vaccinia virus in humans and cattle in southwest region of Sao Paulo state, Brazil. Am. J. Trop. Med. Hyg. 2008, 79, 647-651. [PubMed]

12. Assis, F.L.; Almeida, G.M.; Oliveira, D.B.; Franco-Luiz, A.P.; Campos, R.K.; Guedes, M.I.; Fonseca, F.G.; Trindade, G.S.; Drumond, B.P.; Kroon, E.G.; et al. Characterization of a new Vaccinia virus isolate reveals the C23L gene as a putative genetic marker for autochthonous Group 1 Brazilian Vaccinia virus. PLoS ONE 2012, 7, e50413. [CrossRef] [PubMed]

13. Drumond, B.P.; Leite, J.A.; da Fonseca, F.G.; Bonjardim, C.A.; Ferreira, P.C.; Kroon, E.G. Brazilian Vaccinia virus strains are genetically divergent and differ from the Lister vaccine strain. Microbes Infect. 2008, 10, 185-197. [CrossRef] [PubMed]

14. Ferreira, J.M.; Drumond, B.P.; Guedes, M.I.; Pascoal-Xavier, M.A.; Almeida-Leite, C.M.; Arantes, R.M.; Mota, B.E.; Abrahão, J.S.; Alves, P.A.; Oliveira, F.M.; et al. Virulence in murine model shows the existence of two distinct populations of Brazilian Vaccinia virus strains. PLoS ONE 2008, 3, e3043. [CrossRef] [PubMed] 
15. Campos, R.K.; Brum, M.C.; Nogueira, C.E.; Drumond, B.P.; Alves, P.A.; Siqueira-Lima, L.; Assis, F.L.; Trindade, G.S.; Bonjardim, C.A.; Ferreira, P.C.; et al. Assessing the variability of Brazilian Vaccinia virus isolates from a horse exanthematic lesion: Coinfection with distinct viruses. Arch. Virol. 2011, 156, 275-283. [CrossRef] [PubMed]

16. Oliveira, G.; Assis, F.; Almeida, G.; Albarnaz, J.; Lima, M.; Andrade, A.C.; Calixto, R.; Oliveira, C.; Diomedes Neto, J.; Trindade, G.; et al. From lesions to viral clones: Biological and molecular diversity amongst autochthonous Brazilian vaccinia virus. Viruses 2015, 7, 1218-1237. [CrossRef] [PubMed]

17. Leite, J.A.; Drumond, B.P.; de Souza Trindade, G.; Bonjardim, C.A.; Ferreira, P.C.; Kroon, E.G. Brazilian Vaccinia virus strains show genetic polymorphism at the ati gene. Virus Genes 2007, 35, 531-539. [CrossRef] [PubMed]

18. Assis, F.L.; Borges, I.A.; Ferreira, P.C.; Bonjardim, C.A.; de Souza Trindade, G.; Lobato, Z.I.; Guedes, M.I.; Mesquita, V.; Kroon, E.G.; Abrahão, J.S. Group 2 vaccinia virus, Brazil. Emerg. Infect. Dis. 2012, 18, 2035-2038. [CrossRef] [PubMed]

19. Brum, M.C.S.; Anjos, B.L.; Nogueira, C.E.W.; Amaral, L.A.; Weiblen, R.; Flores, E.F. An outbreak of orthopoxvirus-associated disease in horses in southern Brazil. J. Vet. Diagn. Investig. 2010, 22, 143-147.

20. Trindade, G.S.; Li, Y.; Olson, V.A.; Emerson, G.; Regnery, R.L.; da Fonseca, F.G.; Kroon, E.G.; Damon, I.K. Real-time PCR assay to identify variants of Vaccinia virus: Implications for the diagnosis of bovine vaccinia in Brazil. J. Virol. Methods 2008, 152, 63-71. [CrossRef] [PubMed]

21. Zheng, L.L.; Wang, Y.B.; Li, M.F.; Chen, H.Y.; Guo, X.P.; Geng, J.W.; Wang, Z.Y.; Wei, Z.Y.; Cui, B.A. Simultaneous detection of porcine parvovirus and porcine circovirus type 2 by duplex real-time PCR and amplicon melting curve analysis using SYBR Green. J. Virol. Methods 2013, 187, 15-19. [CrossRef] [PubMed]

22. Venkatesan, G.; Balamurugan, V.; Bhanuprakash, V. TaqMan based real-time duplex PCR for simultaneous detection and quantitation of capripox and orf virus genomes in clinical samples. J. Virol. Methods 2014, 201, 44-50. [CrossRef] [PubMed]

23. Balboni, A.; Dondi, F.; Prosperi, S.; Battilani, M. Development of a SYBR Green real-time PCR assay with melting curve analysis for simultaneous detection and differentiation of canine adenovirus type 1 and type 2 . J. Virol. Methods 2015, 222, 34-40. [CrossRef] [PubMed]

24. Carletti, F.; di Caro, A.; Calcaterra, S.; Grolla, A.; Czub, M.; Ippolito, G.; Capobianchi, M.R.; Horejsh, D. Rapid, differential diagnosis of orthopox- and herpesviruses based upon real-time PCR product melting temperature and restriction enzyme analysis of amplicons. J. Virol. Methods 2005, 129, 97-100. [CrossRef] [PubMed]

25. Fedele, C.G.; Negredo, A.; Molero, F.; Sánchez-Seco, M.P.; Tenorio, A. Use of internally controlled real-time genome amplification for detection of variola virus and other orthopoxviruses infecting humans. J. Clin. Microbiol. 2006, 44, 4464-4470. [CrossRef] [PubMed]

26. Nitsche, A.; Büttner, M.; Wilhelm, S.; Pauli, G.; Meyer, H. Real-time PCR detection of parapoxvirus DNA. Clin. Chem. 2006, 52, 316-319. [CrossRef] [PubMed]

27. Li, Y.; Olson, V.A.; Laue, T.; Laker, M.T.; Damon, I.K. Detection of monkeypox virus with real-time PCR assays. J. Clin. Virol. 2006, 36, 194-203. [CrossRef] [PubMed]

28. Abrahão, J.S.; Guedes, M.I.; Trindade, G.S.; Fonseca, F.G.; Campos, R.K.; Mota, B.F.; Lobato, Z.I.; Silva-Fernandes, A.T.; Rodrigues, G.O.; Lima, L.S.; et al. One more piece in the VACV ecological puzzle: Could peridomestic rodents be the link between wildlife and bovine vaccinia outbreaks in Brazil? PLoS ONE 2009, 4, e7428. [CrossRef] [PubMed]

(C) 2017 by the authors. Licensee MDPI, Basel, Switzerland. This article is an open access article distributed under the terms and conditions of the Creative Commons Attribution (CC BY) license (http:// creativecommons.org/licenses/by/4.0/). 